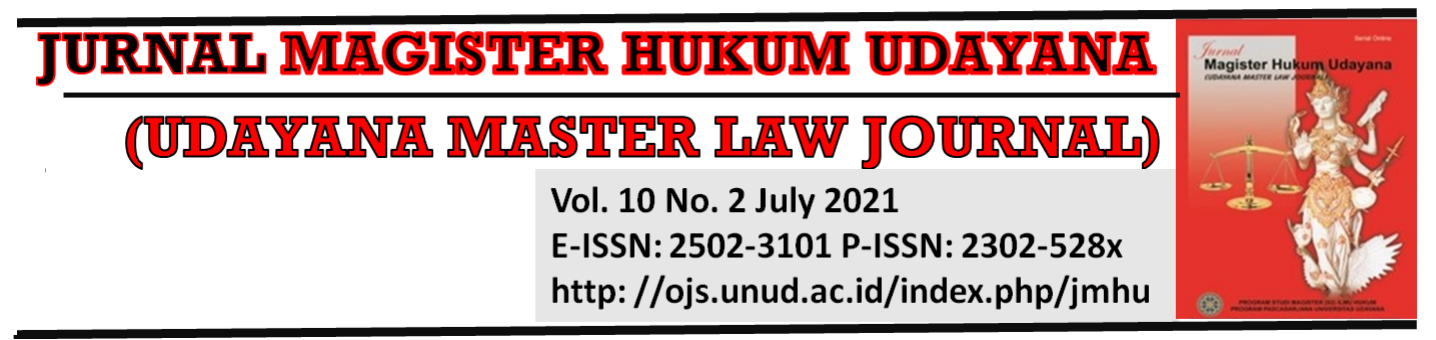

\title{
Combating Narcotics Abuse by Children in Buleleng Regency
}

\section{Dewa Gede Sudika Mangku' ${ }^{1}$ Ni Putu Rai Yuliartini ${ }^{2}$}

${ }^{1}$ Faculty of Law and Social Sciences, Universitas Pendidikan Ganesha,

E-mail: dewamangku.undiksha@gmail.com

${ }^{2}$ Faculty of Law and Social Sciences, Universitas Pendidikan Ganesha,

E-mail: raiyuliartini@gmail.com

\begin{tabular}{l}
\hline Info Article \\
\hline Received: $15^{\text {th }}$ June 2021 \\
Accepted: $22^{\text {nd }}$ July 2021 \\
Published: $31^{\text {st } J u l y ~} 2021$ \\
Keywords: \\
Children; Narcotics; \\
Countermeasures \\
Corresponding Author: \\
Gede Sudika Mangku Email : \\
derwamangku.undiksha@gmail. com \\
DOI: \\
10.24843/JMHU.2021.v10.i02.p06
\end{tabular}

\begin{tabular}{l} 
Abstract \\
\hline Drug abuse is a very worrying problem, especially for young \\
people who will become the heirs and successors of the \\
nation's struggle in the future. Narcotics abuse by children, \\
especially in the Buleleng Regency area is high and is \\
dominated by dhildren aged 14-18 years who are still in school \\
or still receiving education. The high number of narcotics \\
abuse cases in Buleleng Regency at a young age has resulted \\
in greater public concern due to its potentially damaging \\
impact on all dimensions of life. The purpose of this study is \\
to provide an effort to overcome narcotics abuse by dhildren in \\
Buleleng Regency. This research is an empirical legal research \\
using a statutory approadh. Based on the results of the study, \\
it was found that the factors that influence narcotics abuse by \\
children in Buleleng Regency are caused by internal and \\
external factors and efforts to overcome them are carried out \\
by penal efforts (legal dhannels) and non-penal efforts (non- \\
legal dhannels.
\end{tabular}

\section{Introduction}

The development of globalization as it is today, young people seem to have lost their direction and purpose. They are trapped in the environment because of the impact of globalization which puts forward an indifferent attitude and leads more to the nature of anarchism, even many people think that the younger generation does not have a positive influence as an educated person. Factors from advances in technology and information as well as the influx of western cultural influences that entered Indonesia freely caused the moral decline of the younger generation and the values of Pancasila were no longer used as a guide for the younger generation as they are today. ${ }^{1}$ So that many young people are indifferent to the rules and laws that apply in society. From these factors, there

\footnotetext{
1 FHIS Undiksha, "Books Conferences The 1st International Conference on Law and Social Sciences and Education (ICLSSE 2019)," in International Conference on Law and Social Sciences and Education, vol. 1,2019, i-i.
} 
are many problems of concern, especially regarding the behavior of the younger generation who are trapped in drug abuse. Hearing the word narcotics indirectly gives an idea of unwanted effects, this is because narcotics is synonymous with evil, forbidden and violated regulations. ${ }^{2}$

Narcotics abuse among young people is a very worrying problem, it implies to us to care and pay more attention to tackling, because the dangers posed can threaten the existence of the young generation who are expected to become the heirs and successors of the nation's struggle in the future. come. ${ }^{3}$ Narcotics abuse is the use of drugs or other addictive substances outside of medical indications without instructions or a doctor's prescription whose use is pathological (causing abnormalities) and creates obstacles in activities against oneself or social life. ${ }^{4}$

Based on data on the Number of Narcotics Abuse sourced from the annual data on narcotics abuse cases from the Buleleng District Police Narcotics Unit, it can be seen that in 2016 there were 47 cases, of which there were 24 cases of child perpetrators, ${ }^{5}$ in 2017 there were 54 cases, of which the number of perpetrators was there are 25 cases of children, in 2018 there were 55 cases, of which the number of cases of child perpetrators were 28 cases, in 2019 there were 47 cases, of which the number of cases of child perpetrators were 19 cases and in 2020 there were 47 cases, of which the number of cases of child perpetrators was 27 cases. $^{6}$

Of the many cases of narcotics abuse in Buleleng Regency, it can also be seen that more than half of narcotics abusers are dominated by children, which is obtained based on information from the Buleleng Regency Government Official Website, which states that more than half of the narcotics abusers in Buleleng Regency are dominated by children/ adolescents aged 14-18 years who are still in school or are still receiving education. ${ }^{7}$

The high number of narcotics abuse cases in Buleleng Regency at the age of children has resulted in greater public concern due to its potentially damaging

${ }^{2}$ Jumriani Nawawi et al., "Reformulation of Medical Rehabilitation against Victims of Narcotics Abuse in Indonesia," Medico Legal Update 21, no. 1 (2021): 401-5.

${ }^{3}$ Ibid.

${ }^{4}$ Mardani, Penyalahgunaan Narkoba Dalam Perspektif Hukum Islam Dan Hukum Pidana Nasional (Rajawali Pers, RajaGrafindo Persada, 2008). h. 2

${ }^{5}$ Rahma Sugihartati and Daniel Susilo, "Acts against Drugs and Narcotics Abuse: Measurement of the Effectiveness Campaign on Indonesian Narcotics Regulator Instagram," Journal of Drug and Alcohol Research 8 (2019):1-4.

${ }^{6}$ Husni Thamrin and Yi-Ming Liao, "Drug-Related Crimes and Control in Indonesia and Taiwan: Cooperation Regarding Narcotics Smuggling Prevention and Countermeasures from the Point of View of International Law," in International Conference on Knowledge Management in Organizations (Springer, 2018),312-23.

7 I Made Sumada, "Collaboration Policy Of Regional Office Of National Anti-Narcotics Agency With Local Wisdom (Perarem Desa Pekraman) In Bali Handling Drug Abuse," in International Conference on Business, Economic, Social Science and Humanities (ICOBEST 2018) (Atlantis Press, 2018), 466-70. 
impact on all dimensions of life such as social, cultural, political, and economic dimensions. ${ }^{8}$ The impact of narcotics abuse by children that occurs in the midst of society can damage family relationships, drastically reduce learning abilities and work productivity, difficult to distinguish good and bad deeds, anti-social (maladaptive behavior), health problems (physical and mental), rampant levels of violence and traffic violation behavior as well as many more criminal behavior that will be generated. ${ }^{9}$

Narcotics abuse has a very big influence on the state, if there is a massive narcotics abuse in society, then the Indonesian nation will become a fragile nation from within because of declining national resilience. ${ }^{10}$ Therefore, it is very reasonable if the circulation of narcotics must immediately find a rational solution, because narcotics crime is a social problem that can disrupt the social function of society. In addition, narcotics crimes are not always carried out by individual perpetrators but are carried out jointly and even carried out by organized syndicates. Thus, one of the rational efforts used to overcome this is the criminal law policy approach that is used to express what is contained in society and to achieve an aspired goal. ${ }^{11}$

Drug abuse is now not only a national problem, but also an international problem. Therefore, the commitment of the Indonesian people to stop the circulation of narcotics is increasing. This can be seen clearly from the regulation on the use of narcotics including minimum and maximum sanctions for perpetrators. Even though the regulations related to this matter are enforced, narcotics crime is now starting to develop rapidly with a more advanced system from time to time in order to facilitate its circulation in various countries in the world. ${ }^{12}$ In the past, narcotics transactions were still conventional with a face-to-face system and the circulation network could still be counted on the fingers, but nowadays the modus operandi of narcotics transactions has begun to vary with the terms of codes, even through the internet or online. ${ }^{13}$ In response to this, the statutory provisions governing the narcotics issue have been drafted and enforced, but crimes related to narcotics have not been appeased. In various cases that were broadcast in the mass media, both electronic and printed, many dealers and dealers were caught and received severe sanctions, but other actors, such as not feeling afraid, were even

\footnotetext{
8 Nashriana, Perlindungan Hukum Pidana Bagi Anak Di Indonesia, ed. PT Raja Grafindo Persada (Jakarta: Jakarta, 2011).h. 23-24

9 Mardani, Penyalahgunaan Narkoba Dalam Perspektif Hukum Islam Dan Hukum Pidana Nasional. h. 2

${ }^{10}$ Gatot Supramono, Hukum Narkoba Indonesia (Jakarta:Djambatan, 2004). h. 5

${ }^{11}$ Soesilo R, Kriminologi (Pengetahuan Tentang Sebab-Sebab Kejahatan) (Bogor: Politea, 2015). h. 45

12 Vivi Ariyanti, "The Victims of Drugs Abuse and Their Legal Status in the Indonesian Narcotics Law," International Journal of Business, Economics and Law 13, no. 4 (2017): 119-23.

${ }^{13}$ Sofian Syaiful Rizal and Deddy Junaedi, "Educational Efforts In Managing Narcotics Abuse Perspective SANI (Indonesian Anti-Narcotics Celebrities) And BNN (National Narcotics Agency)," PEDAGOGIK: Jurnal Pendidikan 8, no. 1 (2021): 220-59.
} 
more inclined to expand their area of operation. ${ }^{14}$

Related to narcotics crime, it has been regulated in Law Number 35 of 2009 concerning Narcotics. One of the objectives of the enactment of the law is to prevent, protect, and save the Indonesian people from narcotics abuse. So to respond to this, the government in formulating the narcotics law has included rehabilitation in the law. ${ }^{15}$ The statement is contained in Article 54 of the Narcotics Law which states "Narcotics addicts and victims of narcotics abuse are obliged to undergo medical rehabilitation and social rehabilitation". ${ }^{16}$ Where medical rehabilitation can be obtained at hospitals and certain rehabilitation institutions appointed by the minister (Article 56), social rehabilitation can be obtained in government agencies and the community (Article 58). In this case, what the government means is for example the Correctional Institution or LAPAS. ${ }^{17}$

The problem of drug abuse is very complex, both in terms of its causes and its handling. When viewed from the causes of occurrence, drug abuse is caused by many factors that influence each other. ${ }^{18}$ These factors include economic factors, ease of obtaining drugs, family and community factors, personality factors and physical factors of individuals who abuse them. Therefore, the government created all special agencies tasked with preventing and overcoming drug trafficking and abuse, from the national to sub-district levels throughout Indonesia. ${ }^{19}$

Narcotics abuse is a very complex problem, because it requires awareness from all parties, both from the government, society and the perpetrators themselves. The imposition of a crime against a child who is a drug abuser is not wise, it is judged by some who do not agree, and for those who agree, the imposition of a crime is so that the child will not make a deviation again. The position of children in the legal environment as legal subjects is determined by the legal system against children as a group of people who are in legal status and are classified as incapacitated or underage. Inability to mean because of the position of reason and physical growth that is developing in the child concerned. Placing children as legal subjects born from the process of socializing various values

${ }_{14}$ Otto Cornelis Kaligis and D Soedjono, Narkoba Dan Peradilannya Di Indonesia:Reformasi Hukum Pidana Melalui Perundangan Dan Peradilan (Alumni, 2002). h. 260

15 Joko Setiyono, "Integrated Policy Management Of Narcotics Trafficking AS Transnational Organized Crime In Indonesia," Diponegoro Law Review 5, no. 2 (n.d.): 260-76.

16 Bayu Dwa Anugrah and Aryani Witasari, "Legal Policy for Management of Criminal Action of Narcotics in Low Education," Law Development Journal 2, no. 4 (2021): 456-64.

${ }^{17}$ Sangka, Hari. (2003). Narkotika dan Psikotrpika Dalam Hukum Pidana, Bandung: Mandar Maju, 260

18 Sri Wulandari and Sri Hartati, "Community Role in the Prevention of Narcotics Abuse Among Teenagers," in International Conference on Law, Economics and Health (ICLEH 2020) (Atlantis Press, 2020), 411-16.

19 Hartanto Hartanto and Bella Setia Ningrum Amin, "EN The Effectiveness of the Death Penaltv as a Preventive Action in Suppressing the Number of Narcotics Crimes in Indonesia," ScienceRise: Juridical Science,(1 (15)), 2021, 29-37. 
into criminal law events and contractual relationships within the scope of civil law becomes an inseparable link. ${ }^{20}$

Based on the conceptual analysis and empirical conditions as described above, it has strategic value to be studied. Considering that overcoming drug abuse by children is a serious problem in the development of children towards their future, especially if these children are not provided with adequate education regarding the dangers of narcotics. ${ }^{21}$ This complex problem cannot be placed on only one party such as the family or the government, but there needs to be a synergy of cooperation between parents, law enforcement officers, and academics in an effort to deal with these problems. So, the author will discuss the problem of the influence factor of Narcotics in the association of children in Singaraja City, as well as the countermeasures needed to reduce the number of narcotics abuse against children in Buleleng Regency, especially in Singaraja City.

\section{Research Methods}

In this study, empirical legal research will be used. The approach used in this scientific work is a statutory approach. The sources of legal materials used in this study are primary legal materials consisting of applicable laws and regulations. Secondary legal materials consist of research results, text books, scientific journals, newspapers, and internet news that are relevant to the problems being studied. Other non-legal materials such as legal dictionaries, encyclopedias and so on.

\section{Results and Discussion}

\subsection{Factors Influence of Narcotics in Children's Association in Singaraja City}

Every human being in the process of growth experiences various kinds of certain phases that result in physical and mental changes which are usually caused by the maturation process. To determine the criteria for a child, besides being determined by the age limit, it can also be determined from the physical and mental growth and development that is owned because it provides a psychological picture to determine the limits of a child. ${ }^{22}$

Based on Law No. 11 of 2012 concerning the Juvenile Criminal Justice System (Child Criminal Justice System Law) precisely in Article 1 Paragraph 3 regulates "Children in conflict with the law, hereinafter referred to as children, are children who are 12 (twelve) years old. but not yet 18 (eighteen) years of age

${ }^{20}$ Waluyo Mudji, Pedoman Pelaksanaan P4GN (Jakarta: Badan Narkotika Nasional, 2007). h. 123

${ }^{21}$ Yuhernawa Yuhernawa and Megawati Barthos, "Law Enforcement in Treating the Dark Circulation of Narcotics the Border Area of Indonesia," 2021.

22 Dhian Artwitadibrata and Akhmad Khisni, "The Concept of Criminal Law for Personnel of Narcotics Abuse," Jurnal Daulat Hukum 3, no. 4 (2021):411-18. 
who is suspected of committing a crime".

Narcotics are substances or drugs derived from plants or non-plants or not plants, both synthetic and semi-synthetic which can cause a decrease or change in consciousness, loss of taste, reduce to eliminate pain and can cause dependence. Therefore, if this group of substances is consumed by humans, whether it is inhaled, swallowed, or injected, it will affect the nervous system of the brain and will cause dependence. ${ }^{23}$ As a result, the working system of the brain and vital functions of other body organs such as the heart, respiration, blood circulation and others will increase when consuming and will decrease when not consumed (become irregular). ${ }^{24}$

Today, many children's behavior has deviated from what it should be. This is influenced, one of them by the association of the child. ${ }^{25}$ There are factors that cause children to fall into the association of drug abuse, namely internal factors which include: ${ }^{26}$ weak self-control and external factors which include: family factors, environmental factors and economic factors. The truth of these factors agrees with the opinion of social control expert Hirschi, who states that the role of the microsystem plays an important role in the formation of delinquency in a child caused by connections with family, friends, school and other environments. ${ }^{27}$

According to Haryanto, the role of behavior and attitudes as a form of interaction with the surrounding environment such as individuals or certain groups of people also greatly affects a person's self-defense to take an action that deviates from social values prevailing in society. Usually the age range whose self-defense is still relatively weak is the age of 11-20 years where that age is an unstable age for a person to act and act inconsistently according to the influence of the environment or peers. ${ }^{28}$

The internal and external factors of children falling into the association of narcotics abuse are as follows:

1. Internal factors

a) Weak self-control, this is caused by the ignorance of a child in distinguishing acceptable and unacceptable behavior. Usually this is caused by the limited information known to a child so that they

\footnotetext{
${ }^{23}$ Muhammad Fahrul Rizal, "The New Role of Pharmacists to Eradicate Substance Abuse or Medicine by Prevention Program, Combating Drug Abuse and Illict Circulation (P4GN in Indonesia)," Phuture, n.d., 9.

${ }^{24}$ Adami Chazawi, Pelajaran Hukum Pidana (Jakarta: PT Raja Grafindo Persada, 2002). h. 23

25 Ruby Hadiarti Johny, Rani Hendriana, and Dwi Hapsari Retnaningrum, "Problems in Deciding the Case of Narcotics Abuse (The Application of Article 127 of Law No. 35 of 2009 on Narcotics)," in SHS Web of Conferences, vol. 54 (EDP Sciences, 2018), 8003.

26 Ibid..

27 Purwandari E, Keluarga, Kontrol Sosial, Dan "Strain" (Jakarta: Humanitas Jurnal Psikologi Indonesia, 2011).h. 28.

${ }^{28}$ Haryanto, Dampak Penyalahgunaan Narkoba (Bandung: Cipta Pustaka, 2012). h. 58.
} 
are unable to distinguish these behaviors so that a child will tend to be unable to increase self-control which ultimately causes a trait that is easy/easy to be influenced by negative invitations to express him self like abusing narcotics.

2. External factors

a) Family factor, The main factor for a child to abuse narcotics is due to a lack of attention and communication from the family. Harmony in the family has a great influence in demanding an act committed by a child, the quality of family relationships greatly affects the will of a child in abusing narcotics. Therefore, the more harmonious family relationships, the children will not seek an escape outside the home such as abusing narcotics as a form of outlet when a child does not get full affection in the family.

b) Environmental factor, greatly affect how the character or personality of a child is formed. When the environment around the child is good, the behavior expressed by a child will tend to be good, and vice versa, when the child's environment is surrounded by bad people's traits such as promiscuity which refers to drug abuse, the behavior that arises from a child will be so. Environmental factors, such as an invitation from friends, become one of the causes of drug abuse by children because they are surrounded by a bad environment.

c) Economic factor, the economic capacity of a family can be said to be a driving force and a reason for a child to abuse narcotics. Factors in the field can be found that people who abuse narcotics on average are dominated by people who are or have an uppermiddle economic level. Usually, these people are people who have so much busyness or lack of time to rest that they encourage the person to use narcotics in order to increase stamina or relieve depression.

\subsection{Countermeasures Taken in Tackling the Abuse of Narcotics by Children.}

The term countermeasures can be interpreted as an effort made by a government or private institution that has a goal to create a safe and prosperous situation based on existing human rights. ${ }^{29}$ Crime prevention efforts can also be interpreted as an integral part of community protection efforts (social defense) and efforts to achieve welfare (social welfare).

The policy for crime prevention (criminal politics) according to Barda Nawawi Arif can be divided into two paths, namely the penal route (criminal law) and

29 Arief Barda Nawawi, Masalah Penegakan Hukum Dan Kebijakan Hukum Pidana Dalam Penanggulangan Kejahatan (Jakarta: Kencana Prenada Media, 2007). h.17. 
the non-penal route (outside criminal law). Efforts to overcome through the penal route is an effort that focuses on the repressive nature (suppression/eradication/suppression) that is carried out after the crime has occurred. While the non-penal path focuses on the pre-emptive and preventive nature (prevention/deterrence/control).

In terms of efforts to overcome narcotics abuse among children in Buleleng Regency, there are several efforts that can be made to overcome narcotics abuse among children in Buleleng Regency including:

\section{Penalty Countermeasures}

Legal efforts through the penal route are also known as efforts made through criminal law. This effort is a countermeasure effort that focuses more on repressive efforts, namely an effort that is carried out after the crime has occurred by enforcing the law and imposing penalties for crimes that have been committed.

Penal policies are usually repressive in nature, but also contain preventive elements because there are threats and criminal penalties for offenses that are expected to have a deterrent effect. In addition, in dealing with crime, a penal policy will still be needed because criminal law is considered as a means of social policy to channel "social dislike" or social disapproval/social aversion which is also expected to be a means of "social protection". social" (social defense). Therefore, it is often said that "penal policy" is an integral part of "social defense policy" (Arief, 2007: 182).

As for tackling narcotics abuse among children in Buleleng Regency, several related agencies tasked with carrying out countermeasures are the Buleleng Resort Police Narcotics Crime Unit, and the Buleleng Regency BNN. The following are some opinions regarding repressive crime prevention efforts to tackle the crime of narcotics abuse among children in Buleleng Regency, as follows:

a) If the perpetrator reports himself, the $\mathrm{BNN}$ will rehabilitate the perpetrator through medical and social rehabilitation. Medical rehabilitation is an integrated treatment activity carried out in a hospital directly appointed by the Minister of Health. Meanwhile, social rehabilitation is a process of mental and psychological recovery of perpetrators carried out in social rehabilitation institutions appointed by the Minister of Social Affairs. This is in accordance with Article 54 of Law Number 35 of 2009 concerning Narcotics which regulates "Narcotics addicts and victims of Narcotics abuse are required to undergo medical rehabilitation and social rehabilitation". If the perpetrator does not report himself, then the BNN must conduct an investigation related to allegations of narcotics abuse in schools, campuses, and the general public to find out the perpetrators and their 
motives for abusing narcotics, whether as abusers, dealers or narcotics dealers. After knowing the motive, the perpetrator will be processed by law first, especially for narcotics abusers, apart from serving the sentence according to the judge's decision, the perpetrator will also be rehabilitated.

b) If you get a report from the public regarding the alleged abuse or distribution of drugs, the Buleleng District Police will conduct an investigation regarding the allegations reported and then carry out raids for which a raid strategy has been planned in advance to secure the perpetrators and evidence so that further investigations can be carried out. Against the perpetrators in order to secure the perpetrators and evidence before finally being prosecuted and sentenced to a sanction and decision by the judge to rehabilitate the perpetrator.

c) Processing the law on narcotics abusers through the applicable legal rules and following up on the imposition of sanctions that have been determined by the judge. As for the sanctions themselves, narcotics abusers will get rehabilitation guarantees, but it is reaffirmed in the provisions of Article 127 of Law Number 35 of 2009 concerning narcotics that perpetrators can also be convicted and may also lose their right to rehabilitation, unless it can be proven or proven as a victim. narcotics.

If the perpetrator is still a minor who in this study is referred to as a teenager aged 13-17 years in accordance with the provisions of Law Number 11 of 2012 concerning the Juvenile Criminal Justice System, precisely in Article 81 Paragraph (2) stipulates that "The prison sentence that can be imposed is for children not more than (one-half) of the maximum threat of imprisonment for adults".

In addition, since the promulgation of the Law on the Juvenile Criminal Justice System, the term diversion is also known, which is a transition to the settlement of children's cases from the criminal justice process to a process outside the criminal justice system. However, this diversion will only be carried out in the event that the crime committed by the perpetrator is punishable by imprisonment of under 7 (seven) years and is not a repetition of a crime. On this basis, as much as possible law enforcement officers will seek diversion before processing the perpetrator through the criminal justice process.

\section{Non-penal contermeasures}

1) Pre-emptive effort

Pre-emptive countermeasures or also known as non-penal countermeasures are known as efforts to inculcate morals and positive values that are carried out to 
eliminate someone's intention to commit a crime. The principle is, when a person has instilled positive values in him, even if there is an opportunity to abuse narcotics and the intention is gone, that person will not use narcotics.

Several things regarding pre-emptive efforts that can be done by law enforcers, especially the Narcotics Criminal Investigation Unit of Buleleng Regency and BNN of Buleleng Regency to tackle criminal acts of narcotics abuse among children in Buleleng Regency, are as follows:

a) Provide counseling and legal understanding as well as socialization to schools, campuses, and the legal community regarding the dangers of narcotics and the impacts that will be caused if someone falls into narcotics abuse and the sanctions that will be incurred if someone abuses narcotics.

b) Considering that we are still in a COVID-19 situation, pre-emptive efforts can be made through the provision of free online webinars and talk shows as well as the creation of interesting content on social media such as making videos, pamphlets, and even tick-tock about the dangers of drug use and the consequences from its use.

c) Establish a good cooperative relationship with the general public including teachers, lecturers and parents as well as several nongovernmental organizations in conducting counseling and legal understanding to children in Buleleng Regency in order to avoid illicit trafficking and narcotics abuse.

\section{2) Preventive effort}

Preventive efforts, known as follow-up efforts from pre-emptive efforts, are efforts made to eliminate the opportunity for the perpetrator to commit a crime. In this case, usually the effort taken is to carry out direct supervision and monitoring by the authorities in order to close the possibility for the perpetrators to carry out an illicit trafficking and abuse of narcotics. So preventive efforts to tackle narcotics abuse among children in Buleleng Regency are as follows:

a) Establish a good relationship with the general public so that when there are suspicious matters related to illicit trafficking and narcotics abuse, the public can assist the authorities, especially the Buleleng Regency Police Investigation Unit and Buleleng Regency BNN in carrying out preventive efforts to tackle narcotics abuse among children in Buleleng Regency by reporting the suspicious incident.

b) Carry out free urine examinations on a regular basis in order to provide a free service to the community as well as a strategy to attract people to want to report themselves if they have been involved in narcotics abuse.

c) Carry out various kinds of supervision in order to find out and follow 
up on the possibility of abuse and illicit trafficking of narcotics in the community, especially in the environment of children who are very often involved in narcotics abuse. Supervision can be carried out through patrols and disguises carried out by the police or carrying out a crime raid to take firm action against perpetrators of narcotics abuse.

\section{Conclusion}

Drug abuse among young people is a very worrying problem, because the danger posed can threaten the existence of the younger generation who are expected to become the heirs and successors of the nation's struggle in the future. The occurrence of narcotics abuse mainly by children in Buleleng Regency is caused by internal and external factors. Internal factors include weak self-control factors, and external factors include family factors, environmental factors and economic factors.

To overcome this, efforts to overcome narcotics abuse among children in Buleleng Regency can be carried out through penal and non-penal efforts. Penal efforts (repressive efforts) are carried out by: a). implement the Under Cover Buy technique in uncovering the perpetrators; b). carry out medical and social rehabilitation; and c). carry out investigations and raids. Meanwhile, there are two non-penal efforts that can be done, namely by pre-emptive efforts: a). provide socialization and counseling about the dangers of narcotics; $b$ ). holding webinars and online talk shows for free; c). in providing counseling, holding cooperation with teachers, lecturers, and parents as well as non-governmental organizations. And preventive measures: a). establish a good relationship with the community so that when there are things that are suspected regarding the alleged abuse of narcotics, the public can report it to the competent authorities; b). carry out free urine examinations periodically; and c). conduct supervision to follow up on the possibility of abuse and illicit trafficking of narcotics within the community.

\section{References}

Book

Chazawi, Adami. Pelajaran Hukum Pidana. Jakarta: PT Raja Grafindo Persada, 2002.

E, Purwandari. Keluarga, Kontrol Sosial, Dan "Strain." Jakarta: Humanitas Jurnal Psikologi Indonesia, 2011.

Haryanto. Dampak Penyalahgunaan Narkoba. Bandung: Cipta Pustaka, 2012.

Mardani. Penyalahgunaan Narkoba Dalam Perspektif Hukum Islam Dan Hukum Pidana Nasional. Rajawali Pers, RajaGrafindo Persada, 2008.

Mudji, Waluyo. Pedoman Pelaksanaan P4GN. Jakarta: Badan Narkotika Nasional, 2007.

Nashriana. Perlindungan Hukum Pidana Bagi Anak Di Indonesia. Edited by PT Raja Grafindo Persada. Jakarta: Jakarta, 2011.

Nawawi, Arief Barda. Masalah Penegakan Hukum Dan Kebijakan Hukum Pidana Dalam Penanggulangan Kejahatan. Jakarta: Kencana Prenada Media, 2007.

R, Soesilo. Kriminologi (Pengetahuan Tentang Sebab-Sebab Kejahatan). Bogor: Politea, 2015. 


\section{Journals}

Anugrah, Bayu Dwa, and Aryani Witasari. "Legal Policy for Management of Criminal Action of Narcotics in Low Education." Law Development Journal 2, no. 4 (2021): 456-64.

Ariyanti, Vivi. "The Victims of Drugs Abuse and Their Legal Status in the Indonesian Narcotics Law." International Journal of Business, Economics and Law 13, no. 4 (2017): 119-23.

Artwitadibrata, Dhian, and Akhmad Khisni. "The Concept of Criminal Law for Personnel of Narcotics Abuse." Jurnal Daulat Hukum 3, no. 4 (2021): 411-18.

Hartanto, Hartanto, and Bella Setia Ningrum Amin. "EN The Effectiveness of the Death Penalty as a Preventive Action in Suppressing the Number of Narcotics Crimes in Indonesia." ScienceRise: Juridical Science,(1 (15)), 2021, 29-37.

Johny, Ruby Hadiarti, Rani Hendriana, and Dwi Hapsari Retnaningrum. "Problems in Deciding the Case of Narcotics Abuse (The Application of Article 127 of Law No. 35 of 2009 on Narcotics)." In SHS Web of Conferences, 54:8003. EDP Sciences, 2018.

Kaligis, Otto Cornelis, and D Soedjono. Narkoba Dan Peradilannya Di Indonesia: Reformasi Hukum Pidana Melalui Perundangan Dan Peradilan. Alumni, 2002.

Nawawi, Jumriani, Slamet Sampurno, M Syukri Akub, and Nur Azisa. "Reformulation of Medical Rehabilitation against Victims of Narcotics Abuse in Indonesia." Medico Legal Update 21, no. 1 (2021): 401-5.

Rizal, Muhammad Fahrul. "The New Role of Pharmacists to Eradicate Substance Abuse or Medicine by Prevention Program, Combating Drug Abuse and Illict Circulation (P4GN in Indonesia)." Phuture, n.d., 9.

Rizal, Sofian Syaiful, and Deddy Junaedi. "Educational Efforts In Managing Narcotics Abuse Perspective SANI (Indonesian Anti-Narcotics Celebrities) And BNN (National Narcotics Agency)." PEDAGOGIK: Jurnal Pendidikan 8, no. 1 (2021): 220-59.

Setiyono, Joko. "Integrated Policy Management Of Narcotics Trafficking AS Transnational Organized Crime In Indonesia." Diponegoro Law Review 5, no. 2 (n.d.): 260-76.

Sugihartati, Rahma, and Daniel Susilo. "Acts against Drugs and Narcotics Abuse: Measurement of the Effectiveness Campaign on Indonesian Narcotics Regulator Instagram." Journal of Drug and Alcohol Research 8 (2019): 1-4.

Sumada, I Made. "Collaboration Policy Of Regional Office Of National Anti-Narcotics Agency With Local Wisdom (Perarem Desa Pekraman) In Bali Handling Drug Abuse." In International Conference on Business, Economic, Social Science and Humanities (ICOBEST 2018), 466-70. Atlantis Press, 2018.

Supramono, Gatot. Hukum Narkoba Indonesia. Jakarta: Djambatan, 2004.

Thamrin, Husni, and Yi-Ming Liao. "Drug-Related Crimes and Control in Indonesia and Taiwan: Cooperation Regarding Narcotics Smuggling Prevention and Countermeasures from the Point of View of International Law." In International Conference on Knowledge Management in Organizations, 312-23. Springer, 2018.

Undiksha, FHIS. "Books Conferences The 1st International Conference on Law and Social Sciences and Education (ICLSSE 2019)." In International Conference on Law and Social Sciences and Education, 1:i-i, 2019.

Wulandari, Sri, and Sri Hartati. "Community Role in the Prevention of Narcotics Abuse Among Teenagers." In International Conference on Law, Economics and 
Health (ICLEH 2020), 411-16. Atlantis Press, 2020.

Yuhernawa, Yuhernawa, and Megawati Barthos. "Law Enforcement in Treating the Dark Circulation of Narcotics the Border Area of Indonesia," 2021.

\section{Legislation}

Undang-Undang Dasar Negara Republik Indonesia Tahun 1945.

Kitab Undang-Undang Hukum Pidana (KUHP).

Kitab Undang-Undang Hukum Acara Pidana (KUHAP).

Undang-Undang Nomor 35 Tahun 2009 Tentang Narkotika (Lembaran Negara Republik Indonesia Tahun 2009 Nomor 143, Tambahan Lembaran Negara Republik Indonesia Tahun 2009 Nomor 5062).

\section{Online/World Wide Web}

Izarman, Buleleng Masuk Zona Merah Narkotika. diakses dari https://www.patrolipost.com/13435/awas-buleleng-masuk-zonamerahnarkotika/ pada tanggal 11 September 2020.

Pemkab Buleleng, Bahaya Narkoba bagi Pemuda dan Pelajar, Diakses dari https://www.bulelengkab.go.id/detail/artikel/bahaya-narkoba-bagi-remajadan-pelajar-43 pada tanggal 12 September 2020 